Original Research Article

\title{
Assessment of knowledge, attitudes and practice among the post graduate students of dentistry and physiotherapy towards adverse drug reactions reporting and pharmacovigilance at a tertiary care centre at Indore, India
}

\author{
Gopal Gudsurkar1, Vikalp Tiwari²*, Pooja Solanki Mishra²
}

\begin{abstract}
${ }^{1}$ Department of Pharmacology, Dr. Ulhas Patil Medical College and Hospital, Jalgaon,

Maharashtra, India

${ }^{2}$ Department of Pharmacology,

MGM Medical College, Indore, Madhya Pradesh, India
\end{abstract}

\section{Received: 02 March 2018}

Accepted: 12 March 2018

*Correspondence to:

Dr. Vikalp Tiwari,

Email: vikalp.tiwari.mgm@ gmail.com

Copyright: (C) the author(s), publisher and licensee Medip Academy. This is an openaccess article distributed under the terms of the Creative Commons Attribution NonCommercial License, which permits unrestricted noncommercial use, distribution, and reproduction in any medium, provided the original work is properly cited.

\begin{abstract}
Background: Pharmacovigilance knowledge and training in post graduate student doctors is key factor for proper implementation of PvPI. Often the dentists and physiotherapists who are also one of the main stakeholders for ADR reporting are neglected for training and knowledge regarding pharmacovigilance. This study was planned to evaluate the knowledge and awareness of pharmacovigilance in post graduate students in tertiary care centre in Indore.

Methods: It was a single point cross sectional questionnaire-based study conducted in a tertiary care Institute MGM Medical College and M.Y. Hospital in the state of Madhya Pradesh at Indore. It was conducted among post graduate student doctors from dentistry and physiotherapy. Total of 55 questionnaires were distributed, 50 of them were returned back and were analysed.

Results: Overall knowledge level was average. 90\% knew about ADR while 80\% were aware about PVPI. 10\% knew about local AMC at Indore while only $04 \%$ knew global centre for Pharmacovigilance is at Sweden Uppsala. 88\% thought Med watch as global database for ADR against only 12\% knew its Vigibase. 90\% thought ADR reporting is necessary. 96\% thought it should be included in UG curriculum. $98 \%$ had not reported any ADR till date while $84 \%$ had not seen an ADR form.

Conclusions: Post graduate doctors are the prime candidates to impart the importance of pharmacovigilance. The study strongly suggested that there was a great need to create awareness and impart training among the post graduate doctors to improve the reporting of ADRs.
\end{abstract}

Keywords: ADRs, Dentists, Pharmacovigilance, Physiotherapist

\section{INTRODUCTION}

One of the major reasons of morbidity and mortality all over the world is adverse drug reactions (ADRs). Hence, proper monitoring of ADRs is a necessity. Adverse drug reactions can be defined as an appreciably harmful or unpleasant reaction, resulting from an intervention related to the use of a medicinal product, which predicts hazard from future administration and warrants prevention or specific treatment, or alteration of the dosage regimen, or withdrawal of the product. ${ }^{1}$

According to World Health Organization (WHO) definition, an ADR is any noxious, unintended, and undesired effect of a drug, which occurs at the doses which are used in humans for prophylaxis, diagnosis, or therapy. ${ }^{2}$

Whenever any new drug is approved by any authority in any country, little facts are known about its adverse drug 
reactions and side effects known by information from the drug trial and its development.

Here comes importance of pharmacovigilance in which all healthcare professionals and other stakeholders in healthcare like para clinical nursing and also physiotherapists and dentists too are supposed to report the ADR that they encounter or observe in due course of treatment. $^{3}$

The success of a pharmacovigilance program depends upon the active involvement of the all healthcare professionals such as doctors, physiotherapists, dentists,pharmacists even nurses. ${ }^{4,5}$

The ADR reporting rate in India is below 1\% compared to the worldwide rate of $5 \% .^{6}$ To increase this rate of reporting we should educate the all stakeholders of healthcare professionals.

Often, we tend to neglect or ignore the physiotherapists and dentists as reporting stakeholders for pharmacovigilance. So, this study was carried out in the post graduate students of dentists and physiotherapy for assessment of Knowledge, Attitudes and Practice among the Post graduate Students of dentistry and physiotherapy towards Pharmacovigilance.

\section{METHODS}

This was a cross sectional, questionnaire based survey which was conducted in a tertiary care Institute MGM Medical College and M.Y. Hospital in the state of Madhya Pradesh at Indore.

The study instrument was a pre designed 20 questionnaires which were structured to obtain information on the knowledge of the ADRs reporting and the attitudes towards the reporting.13 questions were designed to test knowledge, 4 for attitude and 3 for practice. The doctors were requested to complete the questionnaire and to return it within 1 day to their respective departmental offices.

\section{Inclusion criteria}

All post-graduation pursuing students of MPT [masters in physiotherapy] and MDS [masters in dentistry] across various specialities in this Institute.

\section{Exclusion criteria}

Passed out Post graduate students and senior residents in the respective speciality.

\section{Statistical analysis}

The questionnaire was analysed and question-wise percentage values were calculated with the help of Microsoft excel spread sheet in MS Office 2010.

\section{RESULTS}

Total of 55 questionnaireswere distributed, 50 of them were returned back and were analysed. The percentage based calculation of all the responses were made by taking 55 (the total no. of responders) as the denominator.

Percentage of responders: $(50 / 55)$ X $100=90.90 \%$.

It shows most of the participants were keen towards subject of pharmacovigilance.

There were 13 knowledge based questions mentioned in Table 1. The overall knowledge level of participants was average. The percentage based calculation of all the responses were made by taking 50 (the total no. of responders) as the denominator.

90\% participants knew definition of ADR [45/50].

$80 \%$ participants were aware about PvPI [40/50].

$70 \%$ knew about CDSCO as regulatory body of pharmacovigilance in India [35/50].

$30 \%$ knew about national ADR monitoring centre is at IPC Ghaziabad [15/50].

Mentioned four findings show that participants have learnt and aware about the basic concept of pharmacovigilance programme of India and adverse drug reactions.

Only 20\% knew purpose of Pharmacovigilance is to identify unrecognised ADRs. [10/50].

Only $7 \%$ knew actual definition of pharmacovigilance.[07/50].

04\% knew about location of international apex coordination centre [02/50] and $10 \%$ knew about local ADR monitoring centre [05/50].

$10 \%$ knew that its duty of ALL health stakeholders to report ADR [05/50].

Only $12 \%$ knew about vigibase; the reporting online portal of ADR of WHO [06/50].

Findings show that participants have absolutely poor knowledge about the more deeper aspects of PvPI and ADR reporting.

There were 04 attitude based questions mentioned in Table 2. The percentage based calculation of all the responses were made by taking 50 (the total no. of responders) as the denominator.

$90 \%$ thought ADR reporting is necessary [45/50]. 
$90 \%$ thought it should be made mandatory for all health care professionals [45/50].

96\% thought it should be included in UG curriculum and also our hospital should be made AMC [48/50].
Above findings show that participants had a positive attitude and approach towards the Pharmacovigilance and also eager to implement it in their practice.

Table 1: Percentage responses to knowledge based questions.

\begin{tabular}{|c|c|c|c|}
\hline Questions & $\begin{array}{l}\text { Most frequently } \\
\text { answered } \%\end{array}$ & $\begin{array}{l}\text { Correct answer } \\
\%\end{array}$ & $\begin{array}{l}\text { Most commonly } \\
\text { wrong answered \% }\end{array}$ \\
\hline 1. Do you know what an ADR is? & $\begin{array}{l}\text { Adverse Drug Reaction } \\
45 / 50\end{array}$ & $\begin{array}{l}\text { Adverse Drug Reaction } \\
45 / 50\end{array}$ & $\begin{array}{l}\text { Acute Drug } \\
\text { Reaction } \\
05 / 50\end{array}$ \\
\hline 2. Define Pharmacovigilance? & $\begin{array}{l}\text { The science of } \\
\text { monitoring ADR's } \\
\text { happening in a Hospital } \\
43 / 50\end{array}$ & $\begin{array}{l}\text { The detection, assessment, } \\
\text { understandingand } \\
\text { prevention of adverse } \\
\text { effects } 07 / 50\end{array}$ & $\begin{array}{l}\text { The science of } \\
\text { monitoring ADR's } \\
\text { happening in a } \\
\text { Hospital } 43 / 50\end{array}$ \\
\hline $\begin{array}{l}\text { 3. Are you aware of } \\
\text { Pharmacovigilance Programme of } \\
\text { India? }\end{array}$ & Yes: $40 / 50$ & Yes: $40 / 50$ & No: $10 / 50$ \\
\hline $\begin{array}{l}\text { 4. The important purpose of } \\
\text { Pharmacovigilance is }\end{array}$ & $\begin{array}{l}\text { To calculate incidence } \\
\text { of ADR's } \\
40 / 50\end{array}$ & $\begin{array}{l}\text { To identify unrecognized } \\
\text { ADR's } \\
10 / 50\end{array}$ & $\begin{array}{l}\text { To calculate } \\
\text { incidence of ADR's } \\
40 / 50\end{array}$ \\
\hline $\begin{array}{l}\text { 5. Which of the following methods is } \\
\text { commonly employed by the } \\
\text { pharmaceutical companies to monitor } \\
\text { adverse drug reactions of new drugs } \\
\text { once they are launched in the market? }\end{array}$ & $\begin{array}{l}\text { Meta-analysis } \\
41 / 50\end{array}$ & $\begin{array}{l}\text { Post Marketing } \\
\text { Surveillance (PMS) studies } \\
09 / 50\end{array}$ & $\begin{array}{l}\text { Meta-analysis } \\
41 / 50\end{array}$ \\
\hline $\begin{array}{l}\text { 6. In India which Regulatory body is } \\
\text { responsible for monitoring of ADR's? }\end{array}$ & $\begin{array}{l}\text { Central Drugs Standard } \\
\text { Control Organization } \\
35 / 50\end{array}$ & $\begin{array}{l}\text { Central Drugs Standard } \\
\text { Control Organization } \\
35 / 50\end{array}$ & $\begin{array}{l}\text { Central Drug } \\
\text { Research Institute } \\
15 / 50\end{array}$ \\
\hline $\begin{array}{l}\text { 7. The national centre for monitoring } \\
\text { ADRs in India is located at: }\end{array}$ & $\begin{array}{l}\text { Indian Pharmacopeia } \\
\text { Commission, } \\
\text { Ghaziabad } \\
15 / 50\end{array}$ & $\begin{array}{l}\text { Indian Pharmacopeia } \\
\text { Commission, Ghaziabad } \\
15 / 50\end{array}$ & $\begin{array}{l}\text { AIIMS, New Delhi } \\
35 / 50\end{array}$ \\
\hline $\begin{array}{l}\text { 8. Which of the following is the AMC } \\
\text { of our region? }\end{array}$ & $\begin{array}{l}\text { GMC Bhopal } \\
45 / 50\end{array}$ & $\begin{array}{l}\text { SAIMS Indore } \\
05 / 50\end{array}$ & $\begin{array}{l}\text { GMC Bhopal } \\
45 / 50\end{array}$ \\
\hline $\begin{array}{l}\text { 9. Rare ADRs can be identified in the } \\
\text { following phase of a clinical trial }\end{array}$ & $\begin{array}{l}\text { During phase- } 4 \text { clinical } \\
\text { trials } \\
44 / 50\end{array}$ & $\begin{array}{l}\text { During phase- } 4 \text { clinical } \\
\text { trials } \\
44 / 50\end{array}$ & $\begin{array}{l}\text { During phase- } 3 \\
\text { clinical trials } \\
06 / 50\end{array}$ \\
\hline $\begin{array}{l}\text { 10. The international centre for adverse } \\
\text { drug reaction monitoring is located in }\end{array}$ & $\begin{array}{l}\text { Unites States of } \\
\text { America } \\
48 / 50\end{array}$ & $\begin{array}{l}\text { Sweden } \\
02 / 50\end{array}$ & $\begin{array}{l}\text { Unites States of } \\
\text { America } \\
48 / 50\end{array}$ \\
\hline $\begin{array}{l}\text { 11. The healthcare professionals } \\
\text { responsible for reporting ADR in a } \\
\text { hospital is/are }\end{array}$ & $\begin{array}{l}\text { Doctor } \\
45 / 50\end{array}$ & $\begin{array}{l}\text { Doctor, nurses and } \\
\text { pharmacists } \\
05 / 50\end{array}$ & $\begin{array}{l}\text { Doctor } \\
45 / 50\end{array}$ \\
\hline $\begin{array}{l}\text { 12. Which one of the following is the } \\
\text { 'WHO online database' for reporting } \\
\text { ADRs? }\end{array}$ & $\begin{array}{l}\text { Med watch } \\
44 / 50\end{array}$ & $\begin{array}{l}\text { Vigibase } \\
06 / 50\end{array}$ & $\begin{array}{l}\text { Med watch } \\
44 / 50\end{array}$ \\
\hline $\begin{array}{l}\text { 13. Which of the following scales is } \\
\text { most commonly used to establish the } \\
\text { causality of an ADR? }\end{array}$ & $\begin{array}{l}\text { Schumock and } \\
\text { Thornton scale } \\
48 / 50\end{array}$ & $\begin{array}{l}\text { Naranjo algorithm } \\
02 / 50\end{array}$ & $\begin{array}{l}\text { Schumock and } \\
\text { Thornton scale } \\
48 / 50\end{array}$ \\
\hline
\end{tabular}

There were 03 practice based questions mentioned in Table 3. The percentage based calculation of all the responses were made by taking 50 (the total no. of responders) as the denominator.
$98 \%$ have not reported any ADR till date [49/50].

$84 \%$ have not seen an ADR form [42/50]. 
$84 \%$ did not know how to report [42/50]. 04\% was afraid of legal consequences after reporting [02/50].

Findings show that almost none of the participants have reported any ADR and lack of practice of Pharmacovigilance. Most common reason was they didn't know how to report.

Table 2: Percentage responses to attitude based questions.

\begin{tabular}{|c|c|c|c|}
\hline Questions & $\begin{array}{l}\text { Most } \\
\text { frequently } \\
\text { answered }\end{array}$ & $\begin{array}{l}\text { Correct } \\
\text { answer }\end{array}$ & $\begin{array}{l}\text { Most } \\
\text { commonly } \\
\text { wrong } \\
\text { answered }\end{array}$ \\
\hline $\begin{array}{l}\text { Do you think } \\
\text { Pharmacovigilance } \\
\text { should be taught in } \\
\text { detail during } \\
\text { undergraduate } \\
\text { curriculum? }\end{array}$ & $\begin{array}{l}\text { Yes } \\
48 / 50\end{array}$ & $\begin{array}{l}\text { Yes } \\
48 / 50\end{array}$ & $\begin{array}{l}\text { No } \\
02 / 50\end{array}$ \\
\hline $\begin{array}{l}\text { Do you think } \\
\text { reporting of adverse } \\
\text { drug reaction is } \\
\text { necessary? }\end{array}$ & $\begin{array}{l}\text { Yes } \\
45 / 50\end{array}$ & $\begin{array}{l}\text { Yes } \\
45 / 50\end{array}$ & $\begin{array}{l}\text { No } \\
05 / 50\end{array}$ \\
\hline $\begin{array}{l}\text { Do you think } \\
\text { reporting of ADR } \\
\text { should be made } \\
\text { mandatory for health } \\
\text { care professionals? }\end{array}$ & $\begin{array}{l}\text { Yes } \\
45 / 50\end{array}$ & $\begin{array}{l}\text { Yes } \\
45 / 50\end{array}$ & $\begin{array}{l}\text { No } \\
05 / 50\end{array}$ \\
\hline $\begin{array}{l}\text { Do you think our } \\
\text { hospital should be } \\
\text { AMC? }\end{array}$ & $\begin{array}{l}\text { Yes } \\
48 / 50\end{array}$ & $\begin{array}{l}\text { Yes } \\
48 / 50\end{array}$ & $\begin{array}{l}\text { No } \\
02 / 50\end{array}$ \\
\hline
\end{tabular}

Table 3: Percentage responses to practice-based questions.

\begin{tabular}{|lll|}
\hline Questions & $\begin{array}{l}\text { Most commonly } \\
\text { answered }\end{array}$ & $\begin{array}{l}\text { Correct } \\
\text { answer }\end{array}$ \\
\hline $\begin{array}{l}\text { Have you ever } \\
\text { seen the ADR } \\
\text { reporting form? }\end{array}$ & $\begin{array}{l}\text { No } \\
42 / 50\end{array}$ & $\begin{array}{l}\text { Yes } \\
08 / 50\end{array}$ \\
\hline $\begin{array}{l}\text { Have you ever } \\
\text { reported an ADR? }\end{array}$ & $\begin{array}{l}\text { No } \\
49 / 50\end{array}$ & $\begin{array}{l}\text { Yes } \\
\text { 01/50 }\end{array}$ \\
\hline & -Don't know how to report ADR \\
What practical & $42 / 50$ & -ADRs are already documented \\
difficulties you & in literature 02/50 \\
have in reporting & $\begin{array}{l}\text {-Don't know how to fill up ADR } \\
\text { ADR at our } \\
\text { center? }\end{array}$ & $\begin{array}{l}\text { form 04 /50 } \\
\text {-Fear of legal issues due to } \\
\text { reporting ADR 02/50 }\end{array}$ \\
\hline
\end{tabular}

\section{DISCUSSION}

WHO has defined Pharmacovigilance as the science and activities relating to the detection, assessment, understanding and prevention of the adverse effects (AE), particularly long and short term side effects of medicines or any other drug related problems. ${ }^{7,8}$
Around $32 \%$ and $69 \%$ of drug-related problems were reported as definitely or possibly preventable. It clearly indicates the need of proper and prompt reporting of ADRs from healthcare professionals. ${ }^{9}$

As newer drugs keep on coming in market as a new therapeutic intervention, the risk of ADRs are also keep on increasing. It is found that ADRs account for $4.2-30 \%$ of hospital admissions in USA and Canada and $3.4 \%$ in India. ${ }^{10,11}$

Dental doctors and physiotherapists are also involved in prescribing many therapeutic interventions, including allopathic medicines like local anaesthetics, antibiotics, analgesic and anti-inflammatory drugs etc. Antibiotics and analgesics are among the leading causes of ADRs. ${ }^{12}$ Hence the risk of ADRs cannot be ignored in dentistry and physiotherapy.

Several studies have been done to investigate the cause of underreporting of ADR in Indian medical students. ${ }^{13-15}$ But none such study have been done at our tertiary care centre among post graduate dentist and physiotherapist students. Hence authors planned this study to increase the awareness and practice among Post graduate students at our centre.

Most important thing about KAP studies like these is response of participating candidates. Our study had a very good response rate, $90.90 \%$. It shows most of the candidates were keen towards the subject of pharmacovigilance.

As far as knowledge is concerned, 90\% knew ADR while $80 \%$ were aware about PvPI.

But only $20 \%$ knew its actual purpose to identify unrecognised ADR's. This shows PG students have good approach towards this programme, but they lack the training about it.

$70 \%$ knew the apex body to monitor ADR is CDSCO and only $30 \%$ knew the apex body of PVPI is IPC Ghaziabad. $88 \%$ knew about phase 4 trials in which rare ADR's are identified. Above three values indicate that basic theoretical knowledge about ADR and PvPI is average among the participating post graduates.

Advanced knowledge like local AMC was known to only $10 \%$ while global centre at Sweden Uppsala was known to only $04 \%$. it shows lack of training in PVPI.

There were $90 \%$ thought its only duty of doctors while only $10 \%$ actually knew that any healthcare professional can report an ADR which further highlights importance of training in PVPI among budding dentists and physiotherapists.

Overall knowledge was found to be average level among the participant's. 
Attitude of the participating doctors was very much positive. $90 \%$ said that ADR reporting should be made mandatory to all health care professionals. $96 \%$ were of opinion to include pharmacovigilance from undergraduate syllabus itself and also our tertiary care centre should be made a recognised AMC to report ADR.

Practice part was found to be very much poor. $84 \%$ had never seen an ADR form ever while $98 \%$ never reported any ADR till date. This is a significant observation in this study because this clearly shows total lack of practice and training in PVPI.

The reason behind these findings may be that they are taught about ADR reporting during their under graduation in $2^{\text {nd }}$ year. However, it is not in practice as pharmacovigilance related work has not been included in their undergraduate or post graduate curriculum.

Hence there is strong need to include proper training and practice of pharmacovigilance in undergraduate as well as post graduate curriculum. This will increase the knowledge and practice both in long term.

\section{CONCLUSION}

In conclusion, this study strongly suggested that there was a great need to create awareness among the post graduate doctors to improve the reporting of ADRs. Post graduate doctors are the prime candidates to impart the importance of pharmacovigilance because they are the ones who actively are in touch with patients regularly and also they are future specialists.

Lack of knowledge and training about how to report, purpose of PvPI, lack of risk perception of newly marketed drugs, lack of risk perception of ADRs of prescribed drugs are some of the main causes of the study. Proper training and awareness workshops for post graduate students should be designed keeping these findings in focus.

\section{ACKNOWLEDGEMENTS}

Authors would like to thank all the reporters for reporting and the Pharmacovigilance Program of India for providing the platform to contribute reports to the database.

\section{Funding: No funding sources}

Conflict of interest: None declared

Ethical approval: The study was approved by the Institutional Ethics Committee

\section{REFERENCES}

1. Edwards IR, Aronson JK. Adverse drug reactions: definitions, diagnosis and management. Lancet. 2000;7(356):1255-9.
2. Classen DC, Pestotnik SL, Evans RS. The adverse drug events in hospitalized patients. JAMA. 1997;277(4):301-6. PMID: 9002492. Available at: http://www.ncbi.nlm.nih.gov/pubmed/9002492.

3. Backstrom M, Mjorndal T, Dahlqvist R, NordkvistOlsson T. Attitudes of reporting adverse drug reactions in northern Sweeden. Eur J Clinpharmacol. 2000;56:729-32.

4. Ahmad SR. Adverse drug event monitoring at the Food and Drug Administration. J Gen Intern Med. 2003;18:57-60.

5. Wysowski DK, Swartz L. Adverse drug event surveillance and drug withdrawals in the United States, 1969-2002: The importance of reporting suspected reactions. Arch Intern Med. 2005;165:13639.

6. Amrita P, Kharbanda B. Knowledge, attitude and skills of nurses of Delhi towards adverse drug reaction reporting. Indian J Pharm Pract. 2012;5:45-51.

7. Madhan R, Parthsarathi G. Attitudes and perceptions of medical practitioners-Adverse drug reactions reporting. Asian $\mathrm{J}$ of Pharmaceutical and Clinical Research. 2009;2:184-9.

8. Sweis D, Wong IC. A survey on factors that could affect adverse drug reaction reporting according to hospital pharmacists in Great Britain. Drug Saf. 2000;23:165-72.

9. Caplan LR. Evidence based medicine: Concerns of a clinical neurologist. J Neurol Neurosurg Psychiatry. 2001;71:569-74.

10. Howard RL, Avery AJ, Slavenburg S, Royal S, Pipe $\mathrm{G}$, Lucassen P, et al. Which drugs cause preventable admissions to hospital? A systematic review. Br J Clin Pharmacol. 2007;63:136-47.

11. Arulmani R, Rajendran SD, Suresh B. Adverse drug reaction monitoring in a secondary care hospital in South India. Br J Clin Pharmacol. 2008;65:210-6.

12. Shehab N, Patel PR, Srinivasan A, Budnitz DS. Emergency department visits for antibiotic-associated adverse events. Clin Infect Dis. 2008;47:735-43.

13. Desai CK, Iyer G, Panchal J, Shah S, Dikshit RK. An evaluation of knowledge, attitude, and practice of adverse drug reaction reporting among prescribers at a tertiary care hospital. Perspect Clin Res. 2011;2:12936.

14. Gupta P, Udupa A. Adverse drug reaction reporting and pharmacovigilance: Knowledge, attitudes and perceptions amongst resident doctors. J Pharm Sci Res. 2011;3:1064-9.

15. Ramesh M, Parthasarathi G. Adverse drug reactions reporting: Attitudes and perceptions of medical practitioners. Asian J Pharm Clin Res. 2009;2:10-4.

Cite this article as: Gudsurkar G, Tiwari V, Mishra PS. Assessment of knowledge, attitudes and practice among the post graduate students of dentistry and physiotherapy towards adverse drug reactions reporting and pharmacovigilance at a tertiary care centre at Indore, India. Int J Basic Clin Pharmacol 2018;7:626-30. 